\author{
KINGA KRAWIECKA \\ Uniwersytet Kardynała Stefana Wyszyńskiego \\ $w$ Warszawie
}

\title{
SPEKTAKL MIEJSCE INNEGO - NADZIEJE PEDAGOGA I REŻYSERA
}

W artykule przybliżone zostały rozważania na temat ewoluującego znaczenia istoty teatru oraz teatru jako sztuki poszukiwania drogi życia młodych osób z niepełnosprawnością intelektualną. Kluczowym zadaniem pedagoga specjalnego i reżysera zarazem jest zainicjowanie autokreacji osoby z niepełnosprawnością intelektualną, zaś jednym z możliwych oddziaływań staje się twórczość teatralna w wymiarze cielesności, wolności i języka. W artykule zaprezentowano praktyczne możliwości wykorzystania potrzeby ekspresji, wyrażonej w formie wypowiedzi scenicznej, a także jej autoterapeutyczną rolę w kształtowaniu obrazu własnej osoby.

\section{Stowa kluczowe}

Ewolucja istoty teatru, niepełnosprawność intelektualna, teatr osób z niepełnosprawnością intelektualną, wolność, język, cielesność w praktyce teatralnej. 
„Społeczeństwo zawsze się dużo uczyło, ale przeważnie poza szkoła".

Miejsce Innego jest spektaklem teatralnym, który miałam przyjemność współtworzyć wraz z grupą młodych artystów z niepełnosprawnością intelektualną. Jest widowiskiem specyficznym i oryginalnym w swej treści i formie przekazu. To opowieść o nas, o naszych emocjach, przeżyciach scenicznych, o sztuce zrozumienia: dlaczego taki jestem, o sztuce udźwignięcia ciężaru „ciekawskiego” społeczeństwa oraz sztuce poszukiwania własnej drogi życia - drogi nie tylko wiecznej nadziei. Aby mówić o istocie teatru, należy wspomnieć o tym, czym jest sztuka, a żeby mówić o istocie sztuki, należy odnieść się do działania.

Każdy człowiek stawia sobie fundamentalne pytania o sens życia, o stosunek do siebie, ludzi i świata. Zdarzenia, które stają się udziałem człowieka, niezależnie od wieku, wykształcenia, poziomu intelektualnego, wpisują się w historię jego życia, wyznaczając jednocześnie istotne obszary jego aktywności i praktyki. W tym miejscu pragnę odwołać się do słów Profesora Dietricha Bennera: „działanie może być określane mianem praktyki wówczas, gdy ma swoje źródło w niedoskonałości oraz gdy człowiek zyskuje dzięki niemu powołanie, które nie wypływa bezpośrednio z niedoskonałości, lecz przede wszystkim jest wynikiem jego aktywności”"2.

W związku z powyższym mamy do czynienia z dwoma elementami praktyki: z niedoskonałością człowieka, którą można przekształcać, oraz z możliwością odnalezienia powołania. W tym znaczeniu, praktyką - oprócz etyki, polityki i religii - jest również sztuka ${ }^{3}$. Sztuka „generuje prezentacje świata, które w uwolnionej od działania przestrzeni estetycznego doświadczania i tworzenia świata konfrontują nas ze złożoną struk-

\footnotetext{
${ }^{1}$ Ch. Handy, Glód ducha. Poza kapitalizm. Poszukiwanie sensu w nowoczesnym świecie, Wydawnictwo Dolnośląskie, Wrocław 1999, s. 178.

2 D. Benner, Pedagogika ogólna, tłum. z jęz. niem. M. Wojdak-Piątkowska, w: Pedagogika, t. 1: Podstawy nauk o wychowaniu, red. B. Śliwerski, GWP, Gdańsk 2006, s. 130 .

3 Por. tamże, s. 131.
} 
turą napięć pomiędzy poszczególnymi praktykami”"4. Jak pisała Irena Wojnar, sztuka „to przygoda, spotkanie umysłu ze światem i osobiste jego przyswajanie" ". Tak więc, powyższe pojęcie niesie za sobą potrzebę wyrażania siebie, potrzebę konkretyzacji wewnętrznego świata, zainteresowanie dla tych czynności i radość odczuwaną z samorealizacji.

Jedną z gałęzi sztuki jest teatr. Odwołując się do wcześniej wspomnianych implikacji, należy nadmienić, iż teatr jest miejscem „gdzie na widok publiczny wystawia się blade oblicze istoty wyrwanej z anarchii światłocienia pospolitego życia. Jest instrumentem, który przedstawiając człowieka, odkrywa go na nowo i czyni z egzystencji ciągły akt twórczy"'6.

Każda praktyka, w tym również teatralna, nadaje określony kierunek, dzięki któremu człowiek odnajduje prawdę o sobie samym, celu swojego istnienia, powołaniu oraz otaczającym go świecie, przy jednoczesnej otwartości na kolejną praktykę zorientowaną na dorastanie do pełni człowieczeństwa. Takim też działaniem praktycznym okazał się być spektakl Miejsce Innego. Zakładał on trzy główne idee.

Pierwszą była idea spotkania. Symbolicznie przedstawiliśmy spotkanie $z$ drugim człowiekiem, relację Ja - Ty, która jest istotą naszego bycia w świecie społecznym i kluczowym elementem zmiany. A to, co najważniejsze w spotkaniu i na co zwracaliśmy szczególną uwagę, to doświadczanie siebie poprzez wzajemność i autentyczność. „Podstawowym doświadczeniem - pisał Józef Tischner - i zarazem warunkiem możliwości genezy konstytutywnej Ja w jego «byciu - sobą» jest doświadczenie innego. Doświadczenie to ma dwie strony: ja jestem «inny niż inni», «inni są inni niż ja». Jestem dla nich zupełnie «inny», jestem «osobny», jestem «obcy»"

Skoro mowa o spotkaniu, relacji Ja - Ty, nie sposób nie wspomnieć o podstawowym warunku komunikacji, jakim jest język. To nie tylko sposób porozumienia międzyludzkiego, ale również sposób porozumienia co do treści świata. Jak stwierdza Benner „rozmawiając ze sobą

\footnotetext{
${ }^{4}$ Tamże.

5 I. Wojnar, Teoria wychowania estetycznego - zarys problematyki, PWN, Warszawa 1976, s. 129.

6 A. Hausbrandt, Teatr w spoleczeństwie, WSiP, Warszawa 1983, s. 11.

7 J. Tischner, Spór o istnienie czlowieka, Wydawnictwo Znak, Kraków 1998, s. 221.
} 
i wzajemnie się słuchając, działamy jednocześnie w wymiarze wspomnień i projektów. W słowach przechowywane jest niejako historyczne doświadczanie świata i międzyludzkie porozumienie. W trakcie rozmowy znaczenie słów obejmujące świat i komunikację powstaje wciąż na nowo, a jednocześnie zmienia się dzięki doświadczeniom, które zbieramy w trakcie własnego działania"8.

Drugą ideą była idea spontaniczności, a więc w pewnym sensie wolności w swobodnym wyrażaniu prawdziwych aspektów naszego życia. Tym sposobem przeciwstawiłam się utartym schematom zachowań, sztywnym rolom społecznym, maskom, które nosimy na co dzień. Jak pisał Stanisław Chrobak, „wolność przejawia się na dwóch płaszczyznach: jako samookreślenie się osoby w aktach woli i samookreślenie swego działania. Działanie to urzeczywistnia się poprzez akty decyzyjne, stanowiące syntezę ludzkiego poznania i miłości. Akty bowiem decyzyjne są nieodłączne od osobowego działania człowieka i są zarazem niezbywalne, albowiem poprzez nie dokonujemy autodeterminacji i konstytuujemy siebie realnym źródłem działania"9.

Trzecią ideą, na którą należało zwrócić uwagę w praktyce teatralnej był aspekt cielesności. Oprócz komunikacji językowej, werbalnej, wykorzystaliśmy również komunikację gestem, ruchem, ciałem, dzięki której w równym stopniu mogliśmy czuć, zauważać, przeżywać, rozumieć siebie i innych. Tym bardziej, że ciało człowieka ,nie jest maszyną, którą mógłby sterować, ani autopojetycznym organizmem, w którym byłby ograniczony pod względem swych autorelacji i relacji ze światem. Jest ono raczej organem ludzkiej praktyki w najszerszym tego słowa znaczeniu" 10 .

Pisząc o niedoskonałości człowieka, jego drodze poszukiwania własnego powołania, otwartej na świat cielesności, wolności i werbalności, jednocześnie pragnę nadmienić, iż powyższe aspekty współtworzą eksperymentalny charakter ludzkiej praktyki. W tym miejscu przytoczę kilka istotnych określeń teatru, odwołując się następnie do własnej praktyki.

\footnotetext{
${ }^{8}$ D. Benner, dz. cyt., s. 136

9 S. Chrobak, Podstawy pedagogiki nadziei, Wydawnictwo UKSW, Warszawa 2009, s. 161-162.

10 D. Benner, dz. cyt., s. 133.
} 
Wielcy przedstawiciele teorii i praktyki teatralnej w różny sposób usiłowali określić jej istotę. Ervin Piscator twierdził, że „sztuka jest tylko środkiem wiodącym do celu. Środkiem politycznym. Narzędziem propagandy i wychowania” ${ }^{11}$. Podobnie uważał Leon Schiller: „Teatr był zawsze instytucją propagandową [...] Treść propagandowa zależała od tego, w czyim ręku znajdowała się produkcja i dla jakich celów była przeznaczona" 12 . Słynny dramaturg szwajcarski Max Frisch twierdził natomiast, że swoje zadanie uważałby za dokonane, gdyby w sztuce udało mu się tak postawić pytanie, by widz od tej pory nie mógł żyć bez odpowiedzi. Jean Duvignaud zaś pisał: „można by powiedzieć, że społeczeństwo odwołuje się do teatru, ilekroć pragnie zaafirmować swoje istnienie lub dokonać decydującego aktu, który o nim świadczy; że praxis to przede wszystkim zbiorowy akt twórczy na scenie historii; że jest to zawsze - niemal dokładnie - obraz rewolucji w pojęciu wielu socjalistów i samego Marksa. Czyż egzystencja indywidualna i zbiorowa nie osiąga szczytu, gdy staje się teatralna?"13.

W tym miejscu należałoby zadać sobie pytanie, czym jest teatr dla młodzieży z niepełnosprawnością intelektualną i kim staje się owa młodzież w przestrzeni teatru?

Twórczyni teatroterapii oraz założycielka Fundacji „Teatroterapia Lubelska" Maria Pietrusza-Budzyńska tak pisała o początku swojej praktyki teatralnej z osobami niepełnosprawnymi: „Przyszli do teatru jak do innego wymiaru świata nierealnego, zostawiając za sobą swoje niedoskonałe życie, obciążone i wykolejone przez fakt urodzenia się upośledzonymi umysłowo ludźmi. Dla wielu z nich zetknięcie się ze sztuką, z teatrem było kulturowym szokiem, emocjonalnym rozbiciem, dramatem intelektualnym"14.

${ }^{11}$ Cyt. za: A. Hausbrandt, dz. cyt., s. 13.

12 Cyt. za: tamże.

13 Cyt. za: tamże, s. 15.

14 M. Pietrusza-Budzyńska, Sceniczne pisanie ciałem, w: Sztuka/twórczość - edukacja. Współczesne problemy edukacji estetycznej i artystycznej, red. W. Bobrowicz, Wydawnictwo Verba, Lublin 2010, s. 191. 
Teatr młodzieży z niepełnosprawnością intelektualną jest jak barwna paleta dająca różne możliwości. Ukazuje, jak wprawić uczestników w dobry nastrój, wyzwolić ekspresję ruchową, jak nawiązać kontakt z partnerem, jak w sposób świadomy przeżywać własne doznania, jak zajmujące może być teatralne poszukiwanie, przedstawianie i doświadczanie. Główną jednak możliwością mieszczącą się w barwnej palecie tworzenia jest odnalezienie w sobie człowieka, którego trzeba zagrać na scenie. Dalej Pietrusza-Budzyńska pisze: „Postać rośnie w aktorze na jego podobieństwo, wywodzi się z aktora, z jego konfliktu wobec życia zbudowanego na bazie niepełnosprawności intelektualnej, a następnie na regeneracji siebie, udoskonalaniu swojej osoby, żeby móc uciec do innego wymiaru życia" 15 .

Teatr moich niepełnosprawnych aktorów to laboratorium, w którym mogą wypróbować groźne skutki różnych sytuacji i nauczyć się, jak ich uniknąć lub - co ważniejsze - jak dawać sobie z nimi radę. Teatr to laboratorium, a więc przestrzeń. Przestrzeń, która można by rzec ma wymiar fizyczny, lecz rządzi się prawami wewnętrznymi człowieka. Nie jest jednak całkowicie odrealniona i pozbawiona struktury oraz odniesień do rzeczywistości. Jak dookreśla Anna Bielańska, ,przestrzeń składa się z odzwierciedlenia na scenie relacji między ludźmi i rzeczami. Kształtuje się to poprzez takie wymiary, jak «duży - mały», «blisko - daleko», «powyżej - poniżej». Tak widzimy bowiem zależności między ludźmi, strukturę władzy, stosunek do przedmiotów i zwierząt"16.

Przestrzeń estetyczną można tworzyć dowolnie, zgodnie ze światem wewnętrznym jednostki. Może się ona poszerzać, np. gdy scena przenosi się na koniec świata czy też w tajemniczą krainę nikomu nieznaną, albo też zawężać, gdy poszczególne uczucia pojawiają się w przestrzeni sceny jako konkretne kształty i wiodą spór ze sobą lub blokują konkretne zachowania. Jest ona miejscem, w którym dzięki odgrywaniu ról można odkrywać znaczenie i wartość różnych aspektów życia, takich

\footnotetext{
15 Tamże, s. 192.

16 A. Bielańska, Jacob Levy Moreno i jego idee, [w:] Psychodrama. Elementy teorii i praktyki, red. A. Bielańska, Eneteia Wydawnictwo Psychologii i Kultury, Warszawa 2009, s. 22.
} 
jak: zabawa, taniec, rywalizacja, ambicje czy osiągnięcia, gdzie można nauczyć się empatii, doświadczyć określonych zachowań, doceniając własną witalność, wolę, a przede wszystkim autentyczność. Jak słusznie zauważa Pietrusza-Budzyńska: „Wyznaczone terytorium w teatrze stało się miejscem, na którym poczuli się bezpieczni i tu nabrali poczucia pewności siebie. Wobec swoich ciał mogli na tym terytorium być dumnymi, niezależnie od możliwości i ograniczeń tego ciała" 17 .

Na tle tych mniej lub bardziej teoretycznych rozważań chciałabym teraz podzielić się moimi refleksjami o pracy praktycznej. Od siedmiu lat aktywnie współtworzę teatr osób z niepełnosprawnością intelektualną. Obecnie grupa liczy dziesięciu młodych aktorów niepełnosprawnych w stopniu lekkim i umiarkowanym. Uczestnicząc w kulturze teatru, miałam na uwadze szczególną jego wizję jako wrażenia balansowania między racjami trudno dającymi się zrównoważyć: między wartościami wychowawczymi a rezultatem artystycznym całego procesu „robienia teatru", między spontanicznością i otwartością emocjonalną uczestników a niezbędną dyscypliną kreacji scenicznej, między zrozumiałą ambicją ,pokazania się” a pokorą wobec sztuki i pomysłów na jej tworzenie.

Spektakl Miejsce Innego został zrealizowany w ramach europejskiego programu Grundtvig „Uczenie się przez całe życie”, w którym uczestniczyły: Polska, Belgia, Włochy, Rumunia; charakteryzuje się naturalnością, a zarazem żywą ekspresją, oryginalnością, która jest szaleństwem, bo pokazuje widzom kogoś innego, kogo nie spodziewają się zobaczyć oraz pełną aktywnością twórczą, której rezultatem jest wspólne działanie.

Wraz z muzyką rozpoczyna się ruch. Wsłuchując się w melodię stajemy się tajemniczymi, nieodgadnionymi postaciami. Każda postać sama się kreuje. Powstaje z niczego i wzrasta. Powolnymi, leniwymi ruchami poszczególnych części ciała tworzymy konkretną figurę. Oto początek naszego przedstawienia teatralnego.

${ }^{17}$ M. Pietrusza-Budzyńska, dz. cyt., s. 191. 
Figura jest piękna, kształtna, wdzięczna, opleciona tkaniną, pozostająca w bezruchu, zanurzona w miłości, pragnieniach, bólu życia, desperacji, może nieujawnianej latami. Gdy zmienia się muzyka, wszystkie postacie zaczynają poruszać się płynnie, a zarazem chaotycznie. Każda $\mathrm{w}$ inną stronę. Tkanina unosi się i opada. Ruch się potęguje, a chaos wzrasta. Dopiero poprzez lekkie, wręcz niezauważalne dla widza, muśnięcie każdej z postaci, zmierzamy na swoje miejsca - nieznane miejsca. Każda postać bierze do ręki okarynę ${ }^{18}$. Wtedy można sobie tylko wyobrazić jak lekki, płynny, melodyjny, pełen tajemniczości jest dźwięk, który wydobywa się kolejno z każdego instrumentu. Dźwięki nakładają się na siebie, narastają, aż wreszcie są tak głośne i przenikliwe, że na jeden znak dłoni wszystkie postacie przestają grać. Zapanowuje cisza... przeraźliwa cisza, którą dynamicznie i zdecydowanie przerywa rytm djembe $^{19}$. Wtedy dwie z postaci tanecznym, szybkim krokiem zaczynają poszukiwać siebie nawzajem. Tańczą wokół innych, obracają się, zasłaniają, odkrywają i ponownie zasłaniają, a ich ruchy przenikają się w sposób niebanalny. Czy się odnajdą pośród innych? Czy pozostaną w wiecznym tańcu oczekiwania na...?

To tylko fragment Miejsca Innego, nad którym pracowaliśmy niemal dwa lata. Finał odbył się w maju 2010 roku w Gdańsku. A potem „oklaski, owacje, obrzęd, gdy rozentuzjazmowana publiczność dziękuje aktorom. Ogarnia wszystkich poczucie więzi, przeżycie się potęguje" 20 .

Dzięki odgrywaniu ról można docenić znaczenie i wartość różnych aspektów życia, takich jak: zabawa, taniec, rywalizacja, ambicje czy osiągnięcia. Nauczyć się empatii, doświadczyć różnych zachowań, doceniając własną witalność, wolę, autentyczność. Podstawową zaś cechą wchodzenia $\mathrm{w}$ rolę jest uczenie się i rozwijanie elastyczności w dzia-

\footnotetext{
${ }^{18}$ Ludowy instrument muzyczny o zamiennej nazwie aerofon piszczałkowy, posiadający od 4 do 24 otworów, które - zamykane palcami grającego - kształtują wysokość dźwięku. Wykonujemy go z wypalonej gliny podczas warsztatów ceramicznych.

${ }_{19}$ Afrykański instrument muzyczny, stanowiący rodzaj kielichowego jednomembranowego bębna. Membranę djembe robimy najczęściej z koziej skóry i naciągamy za pomoca sznura bądź śrub.

20 I. Słońska, Wstęp, [w:] Teatr młodzieży, red. I. Słońska, Nasza Księgarnia, Warszawa 1970, s. 9.
} 
łaniu. Sprzyja to większej stabilności psychicznej i lepszemu funkcjonowaniu społecznemu. Gdybym miała wymienić, czego naprawdę nauczyli się moi aktorzy w teatrze, musiałabym opowiedzieć swój dzień, od chwili przebudzenia do głębokiego snu. I cały tydzień. I miesiąc. I rok. I dwa. Obserwując ich na scenie, widzę ich uczucia, fantazje, a poprzez zaistnienie scenicznej magii dostrzegam emocje i zachowania, które nie były wcześniej ujawnione.

„Goethe doskonale umiał obserwować siebie z boku, obiektywnie i bezosobowo. Nawet w najbardziej romantycznych momentach swojego życia nie odmawiał sobie radości posiadania dwóch świadomości. Ta zdolność Goethego dawała mu możliwość głębokiego przenikania w subtelności przeżyć duszy ludzkiej i znalazła odzwierciedlenie w jego twórczości. Taka umiejętność w znacznym stopniu wyzwoli twoje twórcze ja i zacznie coraz częściej obdarowywać cię chwilami natchnienia" 21

Wszystkim, którzy chcą słuchać, opowiadam o poczynaniach moich aktorów - moich przyjaciół - towarzyszy mojego życia, którzy są esencją współdziałań pedagogicznych i teatralnych. Opowiadam o Miejscu Innego, o trudach jakie razem pokonywaliśmy, o braku pomysłów, o lenistwie, zmęczeniu, irytacji, złości, o radości, gdy coś „wyszło”, o dokonaniach, o ich „Inności”, której nie trzeba się bać i o „Miejscu”, w którym powinni się znaleźć, jeśli jeszcze tam nie są. Miejscu, w którym winniśmy zasiąść bezpiecznie ze sobą.

Tę opowieść przekazuję jako dar niezbędny... na lepszą przyszłość. Jako nadzieję... A w skrócie będzie to tak: gdzieś na górze, na nieosiągalnych dla zwykłego śmiertelnika wyżynach ducha, powstało Dzieło. Nieco niżej - młody człowiek, któremu Dzieło to przez wieki oświetlać będzie drogę doskonalenia. A w środku? - Nauczyciel, pośrednik, wychowawca, którego zadaniem jest zmieniać los jego współtowarzyszy, nie tylko teatralny.

\footnotetext{
${ }^{21}$ A. Bielańska, Role i ich znaczenie, [w:] Psychodrama, dz. cyt., s. 66.
} 


\section{BIBLIOGRAFIA}

Benner D., Pedagogika ogólna, tłum. z jęz. niem. M. Wojdak-Piątkowska, [w:] Pedagogika, t. 1: Podstawy nauk o wychowaniu, red. B. Śliwerski, GWP, Gdańsk 2006.

Bielańska A., Jacob Levy Moreno i jego idee, [w:] Psychodrama. Elementy teorii i praktyki, red. A. Bielańska, Eneteia Wydawnictwo Psychologii i Kultury, Warszawa 2009.

Bielańska A., Role i ich znaczenie, [w:] Psychodrama. Elementy teorii i praktyki, red. A. Bielańska, Eneteia Wydawnictwo Psychologii i Kultury, Warszawa 2009,

Chrobak S., Podstawy pedagogiki nadziei, Wydawnictwo UKSW, Warszawa 2009.

Handy Ch., Gtód ducha. Poza kapitalizm. Poszukiwanie sensu w nowoczesnym świecie, Wydawnictwo Dolnośląskie, Wrocław 1999.

Hausbrandt A., Teatr w spoleczeństwie, WSiP, Warszawa 1983.

Pietrusza-Budzyńska M., Sceniczne pisanie ciatem, [w:] Sztuka/twórczość - edukacja. Wspótczesne problemy edukacji estetycznej $i$ artystycznej, red. W. Bobrowicz, Wydawnictwo Verba, Lublin 2010.

Słońska I., Wstęp, [w:] Teatr młodzieży, red. I. Słońska, Nasza Księgarnia, Warszawa 1970.

Tischner J., Spór o istnienie czlowieka, Wydawnictwo Znak, Kraków 1998.

Wojnar I., Teoria wychowania estetycznego - zarys problematyki, PWN, Warszawa 1976.

\section{SPECTACLE PLACE OF THE OTHER - THE HOPES OF EDUCATOR AND PRODUCER}

Consideration have been brought closer in article about evolving meaning essence theater and theater as arts of searches of career paths of young persons with mental handicap. The key task of special educator and at the same time producer is the initiate of autocreation of person is 
with mental handicap and theatrical creation becomes one of possible interaction in dimension of physicality, freedom and communication. It present practical capability of utilization of requirement of expression in article, in the form of stage statement expressed, as well as in forming of personal image of person autotherapeutic role.

\section{Key words}

Evolution of essence of theater, mental handicap, theater of person with mental handicap, freedom, communication, physicality in practice of theater. 
